\title{
Editorial
}

\section{O amor na enfermagem: uma aproximação a partir de Platão}

Em diferentes estudos na área da enfermagem ${ }^{1-3}$, aparecem como atributos, características ou essência da própria área, uma complexa palavra que, por um lado, mostra-se bastante desgastada pelo tempo e, por outro, excessivamente utilizada em contextos tão distintos que termina por perder o seu sentido, qual seja, o amor. Já explicitamos, em outros estudos desenvolvidos no Grupo de Pesquisa Promoção da Saúde e Práticas de Cuidado de Enfermagem e Saúde de Grupos Populacionais, vinculado ao Programa de Pós-Graduação em Enfermagem da Faculdade de Enfermagem da Universidade do Estado do Rio de Janeiro, que o amor se caracterizava como um possível elemento do núcleo central das representações sociais de enfermeiros sobre a enfermagem ${ }^{4}$.

Esta questão é complexa e requer uma profunda análise da filosofia, da história e da epistemologia da enfermagem, além de outras áreas do conhecimento que podem lançar luz sobre esta questão, a fim de delimitá-la devidamente. Certamente, esta ampla apreensão não é o nosso interesse aqui e nem é factível neste momento. Adotamos o objetivo de realizar uma abordagem a partir de Platão $0^{5}$ para compreender, mesmo que de maneira inicial, como o conceito filosófico de amor em Sócrates pode colaborar para uma melhor compreensão da enfermagem e do seu cuidado.

A primeira questão a se apresentar é a da aproximação entre o amor e o belo, sendo este uma profundidade estética que se concretiza na ação correta e boa, no verdadeiro e justo. No contexto do diálogo platônico, base para esta análise - o Banquete ${ }^{5}$, o que não tem esta característica do belo não pode ser fundamento para o amor, ao mesmo tempo em que este impregna o processo de criação da beleza tanto no corpo, quanto no espírito. Assim, o filósofo continua argumentando que o belo se concretiza em estar sensível e em obedecer ao que há de bom e de são em um determinado corpo. Florence Nightingale poderia, com propriedade, completar que a enfermagem teria esta inclinação para o amor e para o belo com vistas a potencializar a saúde e a vida presentes em cada corpo, estimulando as fontes naturais de autorregeneração orgânicas e de integração no conjunto social, cultural e espiritual em que cada pessoa está inserida ao longo de sua existência.

Baseando-nos em Platão, poderíamos definir a enfermagem como a "ciência do amor nos corpos" $5: 34$, compreendendo a sua dinâmica própria, a sua dialética entre o estar pleno e o estar esvaziado, ambos, às vezes, em situações extremas. É a compreensão e o respeito que o enfermeiro deve ter pelo coração do neonato que bate aceleradamente quando comparado ao do adulto e ao mesmo órgão que, em outra pessoa, ao terminar suas atividades, silencia o seu ritmo normal e interrompe o seu trabalho, no momento da morte; ao corpo da mãe que permite o nascimento do bebê quando a natureza o considera em condições de sobreviver externamente, bem como o corpo que não se reconhece mais e produz anticorpos para a sua própria destruição. Todos carregados de significados construídos e compartilhados socioculturalmente.

O amor a ser exercido na enfermagem, fundamento do belo, torna os enfermeiros capazes de perceberem esta dinâmica e de, assim, produzirem um conhecimento, uma técnica e uma sabedoria que limite a sua intervenção neste ciclo ao mínimo possível e ao estritamente necessário. Neste processo, preserva a dignidade humana, a corporeidade como símbolo importante de sua singularidade no mundo e as decisões de cada um, tanto sobre o seu próprio corpo, quanto sobre a sua vida.

Para isto, os enfermeiros que desejam seguir a esteira socrática do amor necessitam pro-vocar o corpo do paciente (ou seja, o levar à sua vocação inicial) de maneira que o próprio corpo permita o nascimento da amizade entre os seus inimigos recíprocos. Isto pode se concretizar na relação estabelecida entre a mente e o coração, a cavidade oral e o estômago, a boca e os órgãos excretores, os desejos sexuais e a adoção de hábitos seguros em sua prática e assim por diante. Este amor reconhece a dialética presente no corpo e reconhece a inimizade que o tempo, a história pessoal, as opções realizadas e as inserções sociais e culturais podem ter configurado ao longo do tempo. $\mathrm{O}$ amor concretiza-se na harmonia que o cuidado de enfermagem pode consubstanciar, aumentando as possibilidades de reversão de quadros patológicos, o aumento da qualidade de vida e o conforto para se enfrentar o adoecimento e a morte. 
Na medida em que o amor, segundo Platão, pode se manifestar no belo, no verdadeiro, no justo e na harmonia, especialmente a corporal, ele também pode ser considerado como "o liame que une o todo a si mesmo" "5:57. Esta harmonia orgânica vem acompanhada da espiritual ao interligar o transcendente com o imanente e preenche o espaço vazio existente entre ambos. Pela senda do absurdo que, às vezes, a vida encaminha à existência humana, a sensação de existência de um todo, que oferece sentido à totalidade da experiência, estimula uma forte integração do negativo (a dor e a tristeza, por exemplo) e do positivo (a vida que continua e a descoberta de novas possibilidades, antes não vislumbradas), permitindo que uma discreta esperança atravesse esta escuridão e os seus dias tenham mais leveza, altivez, dignidade e equilíbrio.

Para Platão, o amor permite a capacidade do nascimento e da procriação no corpo e no espírito. Aqui, de novo, a enfermagem se sente pro-vocada em sua possibilidade de presença significativa ao lado dos pacientes e em sua capacidade de gerar um espaço de sentido que permita, a este corpo e a este espírito, procriar constantemente pensamentos, sentimentos, relações e ações, tornando novo o que envelheceu e transformando em imortal - pelo tempo/duração bergsoniano ${ }^{6}$ que se dá naquele encontro que pode resumir a vida, quer seja conosco mesmos, com os demais ou com o Divino - a incontestável mortalidade dos nossos corpos e de seus elementos constituintes.

Ainda ao abordar este assunto, a imortalidade ocorre, não no mito da eterna juventude e de um ideal de perenidade que se renova automaticamente ao longo dos séculos, mas ao se reconhecer finito em um espaço e tempo, na capacidade que o ser humano tem de transcendê-los na medida em que reconhece a grandeza de seu ser e aceita as possibilidades e as limitações da própria história desenrolada em sua existência. Mostra-se presente, também, na indignação diante das limitações impostas pelas situações e decide construir outro futuro, mesmo que seja um não possível dentro do quadro ordinário atual, chegando a um estado de organização ainda mais elevado do que apresentava anteriormente. E, por fim, a imortalidade concretiza-se na possibilidade de enfrentamento das mágoas e dos conflitos existentes antes que a morte chegue, na palavra dirigida aos que ficam, no compartilhar o medo e o desespero diante da finitude, humanizando a todos que estão envolvidos no processo de morte/morrer e na herança espiritual, social, cultural e intelectual que se deixa, fruto de uma vida aberta ao mundo e às pessoas, com todos os senões que caracterizam a cada um de nós.

A enfermagem pode reafirmar o amor como um dos seus elementos fundamentais ao se basear em Platão e ao considerar que este não é somente um sentimento, um tanto quanto indefinido e impreciso. Trata-se de colaborar para que os pacientes cuidados, mesmo em situações bastante críticas, construam os seus desejos de procriação e de criação enraizados no belo, na justiça, no verdadeiro, na harmonia e na coerência. Para que o ser humano, "em permanente contato com o belo, e em sua companhia, conceba e dê a luz àquelas coisas de que estava prenhe há muito tempo":66 .

Antonio Marcos Tosoli Gomes

Editor Associado

\section{REFERÊNCIAS}

1.Corbani NMS, Brêtas ACP, Matheus MCC. Humanização do cuidado de enfermagem: o que é isso? Rev Bras Enferm. [Internet]. 2009 [citado 12 out 2015]; 62:349-54. Disponível em: http://www.scielo.br/scielo.php?script=sci_ arttext\&pid=S0034-71672009000300003\&lng=pt. http:/dx.doi.org/10.1590/S0034-71672009000300003.

2.Oliveira CP, Kruse MHL. A humanização e seus múltiplos discursos: análise a partir da REBEn. Rev Bras Enferm. [Internet]. 2006 [citado 12 out 2015]; 59:78-83. Disponível em: http://www.scielo.br/scielo.php?script=sci_arttext\&pid=S0034$-71672006000100015 \&$ lng =pt. http://dx.doi.org/10.1590/S0034-71672006000100015.

3.Vale EG, Pagliuca LMF. Construção de um conceito de cuidado de enfermagem: contribuição para o ensino de graduação. Rev Bras Enferm. [Internet]. 2011 [citado 12 out 2015]; 64:106-13. Disponível em: http://www.scielo. br/scielo.php?script $=$ sci_arttext\&pid=S0034-71672011000100016\&lng =pt. http://dx.doi.org/10.1590/S003471672011000100016.

4.Gomes AMT, Oliveira DC. A estrutura representacional de enfermeiros acerca da enfermagem: Novos momentos e antigos desafios. Rev enferm UERJ. 2007; 15:168-75.

5.Platão. O banquete. Rio de Janeiro: Nova Fronteira; 2011.

6.Bergson H. As duas fontes da moral e da religião. Rio de Janeiro: Zahar Editores; 1978. 